\title{
A Monetary Model of Nominal Income Determination
}

\author{
LEONALL C. ANDERSEN
}

D URING the past several years the Federal Reserve Bank of St. Louis has presented a number of empirical studies demonstrating a strong and predictable response of nominal gross national product (GNP) to changes in the nation's money stock. These studies found that changes in the secular trend of the money stock are the prime determinant of changes in the secular trend of GNP. They also found that short-run changes in GNP are related to similar changes in the money stock. On the other hand, changes in Government spending were found to have only a temporary short-rum influence on changes in GNP. A number of other studies, using variations of the approach of the St. Louis studies, have yielded similar empirical relationships.

The St. Louis studies related changes in nominal GNP directly to current and past changes in the money stock and in high-employment Government expenditures. No underlying set of relationships was specified. Instead, the empirical relationship was presented as the reduced-form of an unspecified structure of the economy.

This article sets forth a theoretical model consisting of a set of postulated relationships which form a basis for the relationship of nominal income (GNP) to the money stock and Government expenditures. The theoretical properties of this model are similar to the empirical relationships found in the St. Louis studies. The parameters of the model are estimated for the period from first quarter 1955 to fourth quarter 1973. Empirical tests fail to reject the theory as an explanation of nominal income determination in the sample period.

\section{THEORETCAL MODEL}

This section develops a model of nominal income determination which is based primarily on a prominent

NOTE: This presentation was given as part of the Lawrence H. Seltzer Memorial Lecture Series at Wayne State University, Detroit, Michigan, May 21, 1975. theory of the influence of changes in the money stock on income. ${ }^{1}$ At times, however, assertions different from those in the prominent theory are made. It is also asserted that the responses of holders of money balances to changes in the dependent variables are in relative terms; that is, rates of change or percent discrepancies. The model, therefore, is expressed in log-linear form.

\section{Desired Nominal Money Balances}

The theory underlying this study is based on the assertion that households and business firms desire nominal money balances to conduct market transactions and to hold as a store of value. Specifically, the desired amount of nominal money balances, in the aggregate, depends on the perceived price of newly produced final goods and services, perceived nominal income, the expected rate of inflation, yields on alternative financial assets, and the technical efficiency of the economy's system of making money payments. ${ }^{2}$

Since holders of money balances do not have perfect information regarding market opportunities, and since there exist costs of both collecting information and conducting market transactions, the desire to hold money balances depends on the perceived, instead

\footnotetext{
3 For statements of this theory, see Milton Friedman, "The Denatid for Money: Some Theoretical and Empirical Results," Journal of Political Economy (August 1959), pp; 327-351; "A Theoretical Framework for Monetary Analysis," Jotrnal of Political Economy (March/Apri] 1970), pp. 193238; and "A Monetary Theory of Nominal Income, Journal of Political Economy (March/April 1971), pp. 323-337.

For various asserted forms of the money demand function, see David E. W. Laider, The Demand For Money: Theories and Evidence (Scranton: International Textbook Com pany, 1969). For an excellent statement of the "conventional view" of the money demand function, see Stephen $M$. Goldfeld, "The Denand For Money Revisited,"Brookings Papers on Economic Activity - 3 (1973), pp. 577.638. Also see John T. Booman, "The Evidence on the Demand, for Money: Theoretical Formulations and Empirical Restlts," in John T. Boonnan and Thonas M. Havilesky, Money Supply, Money Demand, and Macroeconomic Models (Boston: Allyn and Bacon, Inc, 1972), pp. 248-291, and Stephen Rousseas, Monetary Theory (New York: Alfred A. Knopf, $1972)$.
} 
of the actual, price of goods and services and nominal income. Given the influences of the other factors, the amount of nominal money balances demanded is positively related to the perceived price of newly produced final goods and services. Given the influences of both perceived price and the other factors, the amount of money balances demanded is positively related to the amount of goods and services that perceived nominal income can purchase.

It is asserted that the response of holders of money balances is of the same magnitude with regard to both perceived price and the amount of goods and services that perceived nominal income can purchase. The desire for nominal money balances, therefore, is formulated in terms of perceived nominal income only (Equation 1).

A continuing rise in the price of goods and services results in a given amount of nominal money balances held as a store of value commanding, over time, a decreasing amount of goods and services. Given the influences of the other factors, the amount of money demanded is negatively related to the rate of inflation expected to prevail in the future (Equation 1).4

Other financial assets are substitutes for money balances as a store of value, and they yield a rate of return. These rates of return, with constant, perceived prices for goods and services, are measured in terms of real rates of interest. To the holder of a financial asset, the real rate of interest is the annual percent increase in the amount of goods and services, at current prices, that a given dollar value of a financial asset will command over the term to maturity. With the influence of other factors held constant, the amount of money demanded is negatively related to real rates of return on alternative financial assets.

It is asserted that the dominant substitutes for money as a store of value are short-term financial

\footnotetext{
Ignoring the other factors,

$\ln \mathrm{M}^{*}=\alpha_{1} \ln \mathrm{PP}^{\mathrm{P}}+\alpha_{2} \ln \frac{\mathrm{YP}^{\mathrm{P}}}{\mathrm{P}^{\mathrm{P}}}=\alpha_{1} \ln \mathrm{P}^{\mathrm{P}}+\alpha_{2} \ln \mathrm{YP}^{\mathrm{P}}-\alpha_{2} \ln \mathrm{P}^{\mathrm{P}}$.

By assertion $\alpha_{1}=\alpha_{2}$; therefore, $\ln M^{\circ}=\alpha_{1} \ln Y^{\mathrm{P}}$. Friedman in "A Monetary Theory of Nominal Income" asserts that for all practical purposes $\alpha_{1}=\alpha_{2}=1$. In this study the only assertion made is that $\alpha_{1}=\alpha_{2}$. The validity of this assertion is tested later in the study and the hypothesis that the two responses are identical cannot be rejected. Friedman's assertion that they both equal unity is also tested and is rejected.

${ }^{4}$ It is important to note that there are two different influences on the amount of money balances demanded related to the price of newly produced final goods and services. One is the positive infuence of the perceived price level for the current period, and the other is the negative influence of the expected rate of change in the price level over the relevant future.
}

assets and that the time horizon upon which expectations of the rate of inflation are based is the same for money balances as for these assets. It is generally accepted that the nominal rate of interest on a financial asset is the sum of the real rate of return and the rate of inflation expected over the term of the financial asset. The nominal short-term interest rate, therefore, is presumed to capture the negative influence on the amount of money demanded of both the real shortterm interest rate and the expected rate of inflation (Equation 1).

The technical efficiency of the system of making money payments is defined as the average amount of money balances required to be held to conduct a given nominal volume of transactions. With the influences of other factors held constant, the amount of money demanded is negatively related to the technical efficiency of the system of making money payments (Equation 1). In other words, the smaller the amount of money balances technically required to be held to conduct a given dollar volume of transactions, the smaller is the amount of money demanded.

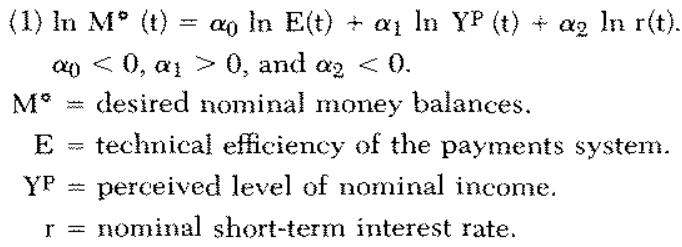

\section{Adiusment of Spending by Households and Business Firms}

The nominal stock of money is assumed to be exogenous, determined by the monetary authorities. Therefore, holders of money balances, in the aggregate, cannot adjust their holdings when a discrepancy occurs between actual and desired money balances. Instead, it is asserted that individual holders of money balances attempt to add to (reduce) money balances by reducing (increasing) their rate of spending on goods and services. Such an adjustment continues until desired money balances are brought into equality with actual money balances.

It is assumed that the rate of change in the dollar volume of spending by households and firms on newly produced final goods and services from both domestic and foreign sources is proportional to the percent discrepancy between actual and desired money balances. ${ }^{5}$ It is also assumed that the response of spending is distributed over time (Equation 2).

5This specification of the adjustment process is a marked de parture from that specified in other studies. Some specify 
(2) $\frac{d \ln Y d}{d t}=\lambda\left[\ln M(t)-\ln M^{*}(t)\right]$.

$\mathrm{M}=$ actual nominal money balances.

$\frac{\mathrm{d} \ln \mathrm{Yd}}{\mathrm{dt}}=\begin{aligned} & \text { rate of change in spending by households and } \\ & \text { business firms for newly produced, final goods }\end{aligned}$ and services.

$\lambda=$ speed of adjustment. $0<\lambda \leqslant \infty$. The larger is $\lambda$, the faster is the speed of adjustment. $\lambda=\infty$ is instantaneous adjustment.

\section{Combining Desined Money}

\section{Balances and Adistment Process}

The preceding assertions regarding the demand for nominal money balances and the adjustment proc-m ess are now combined by substituting equation (1) into equation (2). The result is that the rate of change of nominal spending by households and business firms is related to the level of actual nominal money bal ances, the technical efficiency of the payments system, the level of the nominal short-term interest rate, and the perceived level of nominal income.

(3) $\frac{\mathrm{d} \ln Y \mathrm{~d}}{\mathrm{dt}}=\lambda\left[\ln M(\mathrm{t})-\alpha_{0} \ln \mathrm{E}(\mathrm{t})-\alpha_{1} \ln Y \mathrm{P}(\mathrm{t})-\alpha_{2} \ln \mathrm{r}(\mathrm{t})\right]$

\section{Defunition of Nominal Income}

Nominal income is defined as total value added (that is, factor payments) in the domestic production of new final goods and services. Total nominal spend ing on domestic product is also equal, by definition, to value added. Nominal income, accordingly, is equal to nominal spending for both domestic and foreign product by domestic households, business firms, and all units of govermment, plus nominal spending by foreigners for domestic product, less domestic nominal spending for foreign produced goods and services.

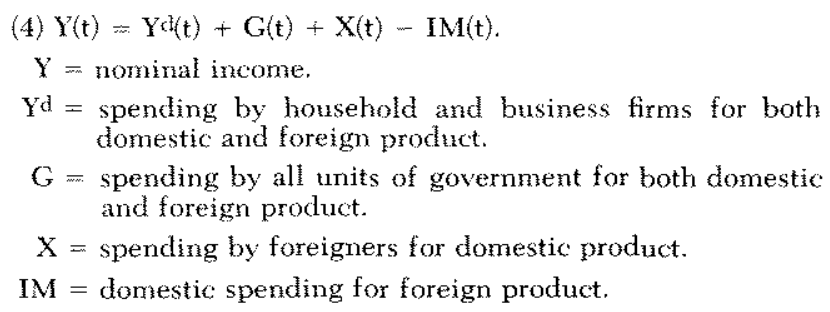

that the actual money stock changes in response to a dism crepancy between actual and desired money balances; others specify that "real" money balances change; and others specify that the short-term interest rate changes. See references in fr. 2 for specific examples of these other specifications. For discussion of the importance of the specification of the adjustment process in enpirical research, see: A. A. Walters, "The Demand for Money - The Dynamic Properties of the Mitliplier," Journal of Political Economy (June 1967), pp. 293-298, and D. R. Starleaf, "The Specification of Money Demand - Supply Models Which Involve the Use of Distributed Lags," Joturnal of Finance (September 1970), pp. $743-760$.

\section{Domestic Spending for Foreign Product}

Domestic nominal spending for foreign product is assumed to be a constant proportion of total nominal spending in the economy.

$(5) \delta(t)=\frac{1 M(t)}{Y^{a}(t)+G(t)+X(t)}=\delta$.

\section{Dymanie Tom of the Model}

The model, up to this point, involves the change in the level of income in response to changes in the level of the money stock, or in Government spending, or in foreign spending on domestic product, or in the short-term interest rate, or in the technical efficiency of the payments system. All of these variables, however, are continuously changing over time. The model is differentiated with respect to time to reflect the response of households and business firms to those variables which are continuously changing.

In its dynamic form, the rate of change in desired money balances is related to the rates of change in the technical efficiency of the payments system, in the short-term interest rate, and in perceived income.

(1) $\frac{\mathrm{d} \ln \mathrm{M}^{\circ}}{\mathrm{dt}}=\alpha_{0} \frac{\mathrm{d} \ln \mathrm{E}}{\mathrm{dt}}+\alpha_{1} \frac{\mathrm{d} \ln \mathrm{Y}^{\mathrm{P}}}{\mathrm{dt}}+\alpha_{2} \frac{\mathrm{d} \ln \mathrm{x}}{\mathrm{d} t}$.

The change in the rate of change in nominal spending by households and business firms is proportional to the discrepancy between the rate of change in actual money balances and the rate of change in desired money balances.

(2) $\frac{\mathrm{d}^{2} \ln \mathrm{Y}^{\mathrm{d}}}{\mathrm{d} \mathrm{t}^{2}}=\lambda\left[\frac{\mathrm{d} \ln \mathrm{M}}{\mathrm{dt}}-\frac{\mathrm{d} \ln \mathrm{M}^{\circ}}{\mathrm{dt}}\right]$.

The statement combining the adjustment process and the factors influencing desired money balances is accordingly modified.

$$
\begin{aligned}
& \text { (3) } \frac{d^{2} \ln Y^{3}}{d t^{2}}=\lambda\left[\frac{d \ln M}{d t}-\alpha_{0} \frac{d \ln E}{d t}-\alpha_{1} \frac{d \ln Y^{2}}{d t}\right. \\
& \left.-\alpha_{2} \frac{\mathrm{d} \ln \mathrm{r}}{\mathrm{dt}}\right] \text {. }
\end{aligned}
$$

Substituting equation (5) into (4) and differentiating with respect to time, the rate of change in nominal income is equal to the weighted sum of the rates of change of spending for product by domestic households and business firms, domestic units of government, and foreigners.

$$
\begin{aligned}
& \text { (4) } \frac{d \ln Y}{d t}=W_{1}(t) \frac{d \ln Y d}{d t}+W_{2}(t) \frac{d \ln G}{d t}+W_{3}(t) \frac{d \ln X}{d t} . \\
& W_{1}(t)=[1-\delta] \frac{Y d(t)}{Y(t)} ; W_{2}(t)=[1-\delta] \frac{G(t)}{Y(t)} ; \\
& \text { and } W_{3}(t)=[1-\delta] \frac{X(t)}{Y(t)}
\end{aligned}
$$




\section{Summory of Varibles}

The endogenous variables of the model are the change in the rate of change in nominal spending by households and business firms, the rate of change in desired money balances, and the rate of change in nominal income. It will also be developed in subsequent analyses that the rate of change in the perceived level of nominal income is an endogenous variable related to past rates of change in nominal income. The exogenous variables are the rates of change in actual money balances, in the short-term interest rate, in the techmical efficiency of the payments system, in Government spending on goods and services, and in foreign spending on domestic product.

The model is one of partial analysis, inasmuch as the nominal short-term interest rate is an exogenous variable. There is no provision for feed-back effects on the rate of change in nominal income. These effects would emanate from changes in exogenous variables which change the rate of change in the short-term interest rate, either by induced changes in the real interest rate or in the expected rate of inflation.

\section{Conditions for Dynamio Equllbrem}

Dynamic equilibrium is defined as the state in which all of the variables are changing at constant rates. ${ }^{6}$ This occurs when the rates of change in actual and desired money balances are equal. Three conditions are required for this equality to be fulfilled changes in the rates of change in nominal spending by households and business firms and in nominal income equal zero (E-1 and E-2), and the rates of change in nominal income and in the perceived level of nominal income are equal (E-3).

(E-1) $\frac{d^{2} \ln Y d}{d t^{2}}=0$.

(E-2) $\frac{\mathrm{d}^{2} \ln \mathrm{Y}}{\mathrm{dt}^{2}}=0$.

(E-3) $\frac{\mathrm{d} \ln \mathrm{Y}^{\mathrm{p}}}{\mathrm{dt}}=\frac{\mathrm{d} \ln \mathrm{Y}}{\mathrm{dt}}$.

0The definition of equilibrium as constant rates of change is a marked departure from the standard literature in monetary economics, other than sone growth models. The standard analysis defines equilibrium as constant levels of the endom genous variables. The equilibrium conditions for the standard analysis would be that desired and actual levels of money balances are equal, that the rates of change in spending by households and business firms and in nominal income equal zero, and that the perceived level of nominal income equals the actual level. Thus, in the standard analysis there is both stock and flow equilibrium. In the dynamic form in this study, however, equilibrium is defined as constant rates of change in both stock and flow variables.

\section{Dynamic Equilibritum State}

The relationships of the model (Equations $3^{\prime}, 4^{\prime}$, and the weights) together with the three dynamic equilibrium conditions (Equations E-1 through E-3) are used to solve for the dynamic equilibrium state of the endogenous variables. ${ }^{7}$ In the dynamic equilibrium state, taking into consideration the postulated signs of the coefficients, the rate of change in nominal spending by households and business firms is positively related to the rates of change in actual money balances, in the technical efficiency of the payments system, and in the nominal short-term interest rate, and is negatively related to the rates of change in government spending and exports (Equation ES-I). The rate of change in nominal income is positively related to the rates of change in actual money balances, in the technical efficiency of the payments system, and in the nominal short-term interest rate (Equation ES-2).

$$
\begin{aligned}
& (E S-1) \frac{d \ln Y d}{d t}=\frac{1}{W_{1}(t) \alpha_{1}}\left[\frac{d \ln M}{d t}-\alpha_{0} \frac{d \ln E}{d t}-\alpha_{2} \frac{d \ln r}{d t}\right. \\
& \left.-W_{2}(t) \frac{d \ln G}{d t}-W_{3}(t) \frac{d \ln X}{d t}\right] . \\
& (E S-2) \frac{d \ln Y}{d t}=\frac{1}{\alpha_{1}}\left[\frac{d \ln M}{d t}-\alpha_{0} \frac{d \ln E}{d t}-\alpha_{2} \frac{d \ln r}{d t}\right] .
\end{aligned}
$$

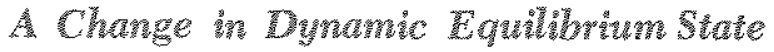

An existing dynamic equilibrium state is disturbed, in this model, by two types of events. One type is the initial creation of a discrepancy between the rates of change in actual and desired money balances. Factors initiating such a discrepancy are changes in the rate of change in actual money balances or changes in the rate of change in desired money balances. This latter change can result from changes in the rate of change in either the technical efficiency of the payments system or in the short-term interest rate. The other type of equilibrium disturbance is a change in the rate of change in government spending or in foreign spending for domestic product, which initiates a change in the rate of change in nominal income. Following both types of disturbance, a new equilibrium state is achieved when the rate of change in nominal income has changed to the extent that the rate of change in desired money balances is brought into equality with the rate of change in actual money balances.

\footnotetext{
"This analysis and the one immediately following is for partial equilibritum only inasmuch as the interest rate is exogenous. The model only considers the inffuence of exogenous shocks on the chotce between money and rew production and not on the choice between money and existing assets.
} 
For example, starting from dynamic equilibrium (that is, all variables changing at constant rates) assume there is a maintained increase in the rate of change in actual money balances, with the rates of change in the other independent variables remaining as they were. First, there occurs a positive discrepancy between the rates of change in actual and desired money balances, resulting in an increase in the rate of change in nominal spending by households and business firms. As a result, there is an increase in the rate of change in nominal income. This latter increase, in turn, results in an increase in the rate of change in perceived nominal income and thereby in the rate of change in desired money balances.

As a result, the discrepancy between the rates of change in actual and desired money balances is narrowed and the rate of change in spending by households and business firms decreases. This decrease reduces the rate of change in nominal income from what it was initially. This process continues until there is equality between the rates of change in actual and desired money balances. In the new dynamic equilibrium state, the rates of change in spending by households and business firms and in nominal income are higher than their starting equilibrium values (ES-1 and ES-2),

In another example, starting from equilibrium, assume there is a maintained increase in the rate of change in government spending, with rates of change in the other independent variables remaining the same. The first response is an increase in the rate of change in nominal income which produces an increase in the rate of change in perceived nominal income. This results in an increase in the rate of change in desired money balances.

As a consequence, there is a negative discrepancy between the rates of change in actual and desired money balances, resulting in a subsequent decrease in the rate of change in spending by households and business firms. This is accompanied by a decrease in the rates of change in nominal income and in perceived nominal income, which, in turn decreases the rate of change in desired money balances. This process continues until the rate of change in desired money balances equals that of actual money balances.

In the new dynamic equilibrium state the rate of change in nominal income is the same as it was before the increase in the rate of change in government spending (ES-2). The rate of change in spending by households and business firms has been permanently decreased (ES-1), affsetting fully the initial increase in the rate of change in nominal income generated by the increase in the rate of change in government spending.

The length of time required for achieving the new equilibrium state depends on (1) the speed of response of the rate of change in spending by households and business firms to a discrepancy between the rates of change in actual and desired money balances and (2) on the length of time required for the rate of change in perceived nominal income to respond fully to past rates of change in actual nominal income. The time path to a new equilibrium - whether it oscillates or moves only in one direction-depends on the response characteristics of the relationships comprising the model.

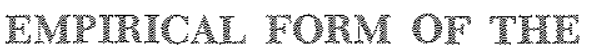 TWEORETUCA MODER}

The theoretical model consists of three relationships. One is for the change in the rate of change in spending by households and business firms (Equation $3^{\prime}$ ). The other two are the identity for the rate of change in nominal income (Equation 4'), and the weights involved in this identity. The theoretical model is next given an empirical form which provides the basis for testing whether or not the theory can be accepted. This section presents the empirical model and the following section uses it to test the theory.

\section{Data Problems}

A major data problem is involved in developing the empirical form of the model - the theory is in terms of changes in time which are infinitesimally small while data on the variables are available only for discrete points in time separated by a month or a quarter of a year. A linear approximation in discrete time is used - the first difference of natural logarithms of a variable between two discrete points in time is presumed to approximate its rate of change (Appendix).

Another data problem exists inasmuch as there are no measurements of the technical efficiency of the payments system or of the perceived level of nominal income. It is assumed that, on average, the technical efficiency of the payments system increases at a constant rate (Appendix) ${ }^{8}$ The second problem is solved

8Examples of developments which are usualy presumed to
have increased the effichency of the payments system (a
reduced amomt of money balances required to carry out a
given volume of money payments) over the sample period 
by employing a procedure presented by Philip Cagan. ${ }^{8}$ According to this procedure, the rate of change in perceived nominal income can be approximated by a weighted average of past rates of change in actual nominal income (Appendix). In this procedure, the weights sum to unity.

\section{Estimated Parameters of the Modet}

Only the parameters of the relationship explaining the change in the rate of change in spending for product by households and business firms are estimated; the other relationships are identities. Two versions of this relationship are estimated. One is based on the assertion that desired money balances are positively related to perceived price and the amount of goods and services that perceived nominal income can purchase, with no assertions regarding the magnitudes of response. The other one is based on the assertion that the magnitude of response of desired money balances is the same with regard to perceived price as with regard to the amount of goods and services that perceived nominal income can purchase - the perceived income formulation used in the theoretical discussion. The general forms of these two relationships are as follows:

$$
\begin{aligned}
& \text { (A) } \Delta \ln \mathrm{Y}_{\mathrm{t}}^{\mathrm{d}}-\Delta \ln \mathrm{Y}_{\mathrm{t}-1}^{\mathrm{d}}=\mathrm{a}_{0}+\mathrm{a}_{\mathrm{l}} \Delta \ln \mathrm{M}_{\mathrm{t}}+\mathrm{a}_{2} \Delta \ln \mathrm{r}_{\mathrm{t}} \\
& +a_{3} \sum_{i=1}^{n} w_{i} \Delta \ln P_{t+i}+a_{4} \sum_{j=1}^{n} w_{i} \Delta \ln Q_{t w j}+E_{t} \\
& \text { (B) } \Delta \ln Y_{t}^{\ddagger}-\Delta \ln Y_{i-1}^{d}=b_{0}+b_{1} \Delta \ln M_{t}+b_{2} \Delta \ln r_{t} \\
& +\mathrm{b}_{3} \underset{\mathrm{i}}{\stackrel{\mathrm{n}}{2} w_{1}} \mathrm{w}_{\mathrm{i}} \Delta \mathrm{ln}_{\mathrm{n}} \mathrm{Y}_{\mathrm{t}-\mathrm{i}}+\varepsilon_{\mathrm{t}} \text {. } \\
& \Delta \ln \mathrm{Y}_{\mathrm{t}}^{\mathrm{d}}-\Delta \ln \mathrm{Y}_{\mathrm{t}=\mathrm{I}}^{\mathrm{G}}=\text { change in the rate of change in sperding } \\
& \Delta \ln \mathrm{M}_{\mathrm{i}} \quad \text { = rate of change in nominal money balances. } \\
& \Delta \ln \mathrm{r}_{\mathrm{t}} \quad=\text { rate of change in nominal short-term } \\
& { }_{\mathrm{N}}^{\mathrm{n}} \mathrm{w}_{\mathrm{i}} \Delta \ln \mathrm{P}_{\mathrm{t}-\mathrm{i}}=\text { interest rate. } \\
& \text { price. } \\
& { }_{\Sigma}^{\mathrm{n}} w_{\mathrm{i}} \triangle \mathrm{In} \mathrm{Q}_{t-\mathrm{i}}=\text { weighted sum of past rates of change in } \\
& \varepsilon_{\mathrm{t}}=\mathrm{a} \text { random error term. }
\end{aligned}
$$

are the introduction of faster means of transferring funds and the adoption of improved methods of managing money balanees. See George Garvy and Martin $\mathrm{R}$. Blyn, The Velocw ity of Monet (New York: Federal Reserve Bank of New York, 1969), pp. 207-218, for further discussion of this point.

"Phillip Cagan, "The Monetary Dynamics of Hyperinflation," Studies in the Quantity Theory of Money, ed. Milton Friedman (Chicago: University of Chicago Press, 1956), pp. 31-41.
Ordinary least-squares regressions, using quarterly data from first quarter 1955 to fourth quarter 1973 , are used to estimate the parameters of equations $\mathrm{A}$ and B. Spending by households and business firms is measured by the sum of consumption plus investment in the national income accounts. Nominal income is measured by nominal GNP. ${ }^{10}$ The price level is measured by the GNP deffator, and the amount of goods and services that nominal income can purchase is measured by nominal GNP divided by the price deflator. Two definitions of money are used. One $\left(\mathrm{M}_{1}\right)$ is the sum of demand deposits and currency held by the nonbank public. The other one $\left(\mathrm{M}_{2}\right)$ is $\mathrm{M}_{1}$ plus time and savings deposits at commercial banks, other than large, negotiable certificates of deposit. The short-term interest rate is measured by the 4- to 6- month commercial paper rate. Two zero-one dummy variables are included for the average influence of major strikes on income, with $\mathrm{D}_{1}$ equaling one for the quarter of a strike and $D_{2}$ equaling one for the quarter following a strike. ${ }^{11}$

A test was performed for a structural change in the model (Appendix). For $M_{1}$ such a change is alleged by some analysts to have occurred after the fourth quarter of 1966 when a change in the trend growth of the ratio of GNP to $M_{1}$ is observed. A similar change in the trend growth of the ratio of GNP to $\mathrm{M}_{2}$ occurred after the fourth quarter of 1961. In both cases the structural change hypothesis was rejected. A statistical procedure (Appendix) was next used to select the appropriate number of lagged changes in the price level, nominal income, and in the amount of goods and services that nominal income can purchase; four lagged terms were deemed appropriate. The estimated parameters of equations $\mathrm{A}$ and $\mathrm{B}$ are reported in Tables I and II.

\section{EMPIRICAL MODEL AS A TEST OF THE THEORY}

The empirical model is used to test whether or not the theory of nominal income determination advanced earlier can be accepted. The part of this theory regarding the determination of nominal spending by households and business firms carries specific implica-

\footnotetext{
10In national income terms, the definition of nominal income used in this study is the sum of consumption, investment, government expenditures, and exports less imports. This sim should be adjusted for depreciation and indirect business taxes, to be identical to value added. It is assumed that variations in these two magritudes will have little infuence on the outcome of this study.

11The major strikes in the sample period were: steel III/1959, autos IV $/ 1964$, and autos IV $/ 1970$.
} 
Table I

\begin{tabular}{|c|c|c|}
\hline $\begin{array}{l}\text { Independent } \\
\text { Yartibble. }\end{array}$ & Regression Results & $\mathrm{M}_{2}$ \\
\hline$\theta_{1}$ & $\begin{array}{l}1,996 \\
(-3765)\end{array}$ & $\begin{array}{r}-1947 \\
(-3,637)\end{array}$ \\
\hline $\mathrm{D}_{2}$ & $\begin{array}{r}2,250 \\
139781\end{array}$ & $\begin{array}{c}1,921) \\
(3,32)\end{array}$ \\
\hline$\Delta \mathrm{nn}$ & $(4,003)$ & $\begin{array}{r}334 \\
(3.014)\end{array}$ \\
\hline$\Delta \mathrm{ln} \mathrm{n}$ & $\begin{array}{r}022 \\
2,257)\end{array}$ & $\begin{array}{r}032 \\
1300961\end{array}$ \\
\hline$\Delta \mathrm{n} Q \mathrm{t}$ & $\begin{array}{l}797 \\
(-5,250)\end{array}$ & $\begin{array}{r}799 \\
-5.182\end{array}$ \\
\hline$\Delta n_{n} Q_{2}$ & $\begin{array}{l}249 \\
(1205)\end{array}$ & $\begin{array}{r}208 \\
1,580\end{array}$ \\
\hline$\Delta n Q_{13}$ & $\begin{array}{l}263 \\
12,0511\end{array}$ & $\begin{array}{r}238 \\
(1842)\end{array}$ \\
\hline$\triangle \ln \mathrm{O}_{4}$ & $\left.l_{2}, 341\right)$ & $\begin{array}{r}301 \\
-2,518)\end{array}$ \\
\hline$\triangle \mathrm{nr} \mathrm{s}$ & $\left(2_{2}, 105\right)$ & $(-1,855)$ \\
\hline$\Delta n P_{t}$ & $\begin{array}{l}5508 \\
1,193)\end{array}$ & $\begin{array}{r}392 \\
-1,254)\end{array}$ \\
\hline$\Delta n P_{-3}$ & $(1,293)$ & $\begin{array}{r}232 \\
(479)\end{array}$ \\
\hline$\Delta \mathrm{ln} \mathrm{P}$ & $\begin{array}{l}251 \\
606)\end{array}$ & $\begin{array}{l}274 \\
(657)\end{array}$ \\
\hline Constont & $\begin{array}{l}1074 \\
(3078)\end{array}$ & $\begin{array}{r}772 \\
2135\end{array}$ \\
\hline$R^{2}$ & $\$ \$ 60$ & 561 \\
\hline SEE & 875 & 883 \\
\hline ow & 2009 & 2.037 \\
\hline
\end{tabular}

Wumbers in parentheses are t-wilues.

tions regarding the estimated coefficients reported in Tables I and II. If the estimated coefficients are consistent with the implied coefficients, at the five per. cent level of statistical significance, this part of the theory is accepted.

The model as a whole constitutes the theory of nominal income determination. This theory is tested by the ability of the empirical model to forecast nominal income. ${ }^{12}$ Relatively small root mean squared errors in forecasting nominal income are taken as evidence that the theory of nominal income determination can be accepted.

\section{Testing Implications of Theory Regarding the Responses of Households and Business Frns}

It was asserted in the theoretical section that the response of holders of money balances is of the same

\footnotetext{
12A more appropriate test would be to solve for the reducedfom of the model, and then to test whether the estimated coefficients of this equation are consistent with those implied by the theory. The reduced-form is a nonlinear equation with variable coefficients, which poses some very difficult problems of estimation. The forecasting test was therefore selected.
}

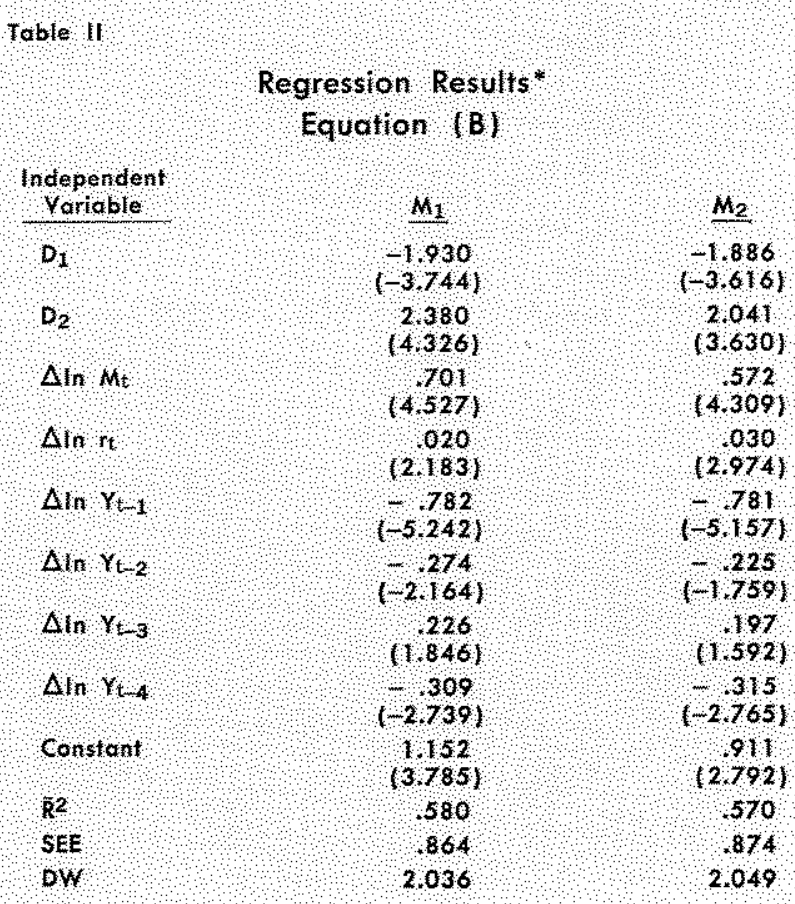

Nembers in parentheses are - values

magnitude with regard to perceived price as with regard to the amount of goods and services that perceived nominal income can purchase. Therefore, the theoretical formulation was in terms of perceived nominal income. This assertion implies in Equations $A$ and $B$ that for each lag the coefficients for the rates of change in price, in the amount of goods and services that nominal income can purchase, and in nominal income are equal. This implication was tested and could not be rejected at the five percent level of statistical significance (Appendix).$^{13}$ As a result of this test, estimates of the coefficients of Equation B are used for the balance of this study (Table II).

The theory of determination of nominal spending by households and business firms implies that all of the coefficients in Equation B are statistically signifcant from zero at the five percent level and that they have the following signs: $b_{0}, b_{1}$, and $b_{2}$ are positive and $b_{3}$ is negative. ${ }^{14}$ All of the estimated coefficients in Table II are statistically significant from zero at the five percent level and have the implied signs. The

1"The proposition that the elasticity of desired money balances with respect to the perceived level of nominal income equals unity was tested and rejected (Appendix). The proposition that this elasticity is greater than unity was accepted.

14These implied signs are derived by applying the postulated signs for Equations $I^{\prime}$ and $2^{\prime}$ to Equation 3 '. The magnitude of $b_{s}$ is derived by adding the coefficients on the lagged income terms. 
empirical evidence is consistent with the implications of this part of the theory, which is, therefore, accepted.

\section{Testing Theory of Nominal Income Determination}

A test of the theory of nominal income determination is the ability of the empirical form of the model to forecast nominal income with relatively small root mean squared errors. This forecasting ability of the model is determined by dynamic simulations. In a dynamic simulation actual values of the quarterly rates of change in money balances, in government spending plus exports, and in the nominal short-term interest rate are used. At the start of the simulation, actual lagged rates of change in nominal income are used, but, subsequently, simulated rates of change are incorporated. Two types of simulations are performed - ex post for the sample period and a number of ex ante simulations beyond various sample periods.

The simulation model consists of Equation B (Table II), Equation $\left(4^{\prime}\right)$, and the definition of the weights. Using the discrete-time linear approximation to rates of change in Equation (4'):

$$
\begin{aligned}
\Delta \ln Y_{t} & =W_{t} \Delta \ln Y_{t}^{d}+\left(1-W_{t}\right) \Delta \ln Z_{t} . \\
W_{t}= & (1-\delta) \frac{Y_{t-1}^{d}}{Y_{t-1}} . \\
Z= & \text { government spending plus exports, } \\
\delta= & \text { ratio of imports to total spending on product. The ratio } \\
& \text { is held constant at its average value in the sample } \\
& \text { period. }
\end{aligned}
$$

Ex post simulations are used to ascertain the ability of the model to capture movements in nominal income over the sample period. The root-mean-squarederror (RMSE) for the quarterly rates of change of nominal income (expressed as annual rates) is 2.85 percentage points using $\mathrm{M}_{1}$ and 2.95 using $\mathrm{M}_{2}$. Although the errors in the quarterly rates of change (expressed as annual rates) are quite large, the errors tend to be offsetting over the sample period. In the fourth quarter of 1973, the error in the level of nominal income was 0.36 percent using $\mathrm{M}_{1}$ and 0.33 percent using $\mathrm{M}_{2}$. Over the sample period, the RMSE for the quarterly levels of nominal income is $\mathbf{1 . 5 7}$ percent using $\mathrm{M}_{1}$ and 2.07 percent using $\mathrm{M}_{2}$.

Ex ante simulations are used to determine the ability of the model to forecast nominal income beyond a sample period, with known values of the exogenous variables. The coefficients of Equation $B$ are estimated for the sample period from first quarter 1955 to fourth quarter 1961. The coefficients are then re-estimated for the sample period from first quarter 1955 to fourth quarter 1962. This procedure of lengthening the sam- ple period by four quarters is continued until fourth quarter 1973, the terminal date.

Dynamic simulations are then performed for the eight quarters following each sample period. The simulated annual rate of change in nominal income over the first four quarters and over the entire eight quarters are calculated. For the set of first four quarters, using all the post sample periods, the RMSE's of the annual rate of change in nominal income are 1.59 percentage points using $M_{1}$ and 1.40 using $\mathrm{M}_{2}$. For the set of eight quarter periods, the RMSE's are 0.99 percentage points using $\mathrm{M}_{1}$ and 0.82 using $\mathrm{M}_{2}$.

For each post sample period, the simulated level of nominal income is calculated for the fourth quarter and the eighth quarter. The RMSE's are then calculated for the set of all post sample periods. Using $M_{3}$, the RMSE in the fourth quarter level of nominal income is 1.59 percent and using $\mathrm{M}_{2}$ is 1.40 percent. For the eighth quarter level, the RMSE is 1.98 percent using $M_{1}$ and 1.64 percent using $M_{2}$.

The ex ante simulation results indicate that the empirical model forecasts the level of nominal income with relatively small RMSE's, compared with forecasts from nine major econometric models of the U.S. economy. Carl $\mathrm{F}$. Christ, in reviewing the ex ante forecasting performance of these models, concluded, "All have RMSE's for real and nominal GNP that are 1 percent or less for one quarter ahead, and 3 percent or less for five or six quarters ahead." The model presented in this study, which is based on a markedly different theory than eight of these nine models, forecasts nominal GNP with smaller RMSE's than several of the large scale econometric models of the U.S. This forecasting evidence thus leads to acceptance of the theoretical model of nominal income determination.

\section{CONCLUSTONS}

A theoretical model of nominal income determination was developed, based on a set of postulates regarding the behavior of households and business firms. The central postulate is that the rate of change in nominal spending by households and business firms for newly produced final goods and services responds to a discrepancy between the rates of change in actual and desired nominal money balances.

On the basis of the empirical tests, the theoretical model was accepted as representing the determination

\footnotetext{
${ }^{15}$ Carl F. Christ, "Judging the Performance of Econometric Models of the U.S. Economy," International Economic Review (February 1975), p. 64 .
} 
of nominal income in the period 1955-1973. The estimated coefficients of the empirical model have the signs implied by the theory. In addition, ex post and $e x$ ante dynamic simulations indicate that it forecasts nominal income with relatively small errors.

The empirical results mentioned in the introduction of the St. Louis reduced-form equation relating changes in GNP to changes in money and government spending are consistent with the theoretical properties of the model presented in this study. These theoretical properties are developed in the section which discusses the changes in the dynamic equilibrium state.

A theoretical property of the model is that a change in the trend growth of nominal money balances changes the trend growth of nominal income. Another theoretical property is that short-run changes in the growth of nominal balances result in short-run changes in the growth of nominal income. A third theoretical property (based on partial analysis) is that changes in the growth of government spending exert a short-run, but not a long-run, influence on growth of nominal income. Thus, there is "crowding-out" of spending by households and business firms, but only in partial equilibrium analysis. Since the desire to hold money balances is negatively related to the short-term interest rate, the financing of the growth of government expenditures by issuing debt may have a positive influence on growth on nominal income. The estimated interest elasticity of desired money balances is very small (about, 03 ); therefore, for debt financing to have much of an influence on growth of nominal income, the elasticity of the interest rate with respect to government debt must be very large or the increase in debt outstanding must be exceedingly large.

\section{APPENDIX}

\section{Daha Problems}

The linear approximation of rates of change in discrete time is given by the following:

$\frac{\mathrm{d} \ln Y}{\mathrm{dt}}=\frac{1}{\mathrm{Y}} \frac{\mathrm{d} \mathrm{Y}}{\mathrm{dt}} \approx \ln \mathrm{Y}_{\gtrless}-\ln \mathrm{Y}_{\mathrm{t}-1}$.

The technical efficiency of the payments system is assumed, on average, to increase at a constant rate given by the following exponential growth function:

$$
\begin{aligned}
E(t) & =a e^{b a} \text {; or } \ln E(t)=\ln a+b t . \\
e & =\text { the base of natural logarithms. } \\
b & =\text { constant rate of growth. } \\
a & =\text { beginning level of } E . \\
t & =\text { an index of time. }
\end{aligned}
$$

Differentiating with regard to time yields;

$$
\frac{\mathrm{d} \ln E}{\mathrm{~d} t}=\mathrm{b} \text {. }
$$

A variation of Phillip Cagan's procedure is used for approximating the rate of change in the perceived level of nominal income. It is assumed that changes in the rate of change in the perceived level of nominal income are proportional to the discrepancy between the actual rate of change in nominal income and the rate of change in the perceived level of nominal income.

$\frac{\mathrm{d}^{2} \ln \mathrm{Y}^{\mathrm{P}}}{\mathrm{dt^{2 }}}=\beta\left[\frac{\mathrm{d} \ln \mathrm{Y}}{\mathrm{dt}}-\frac{\mathrm{d} \ln \mathrm{Y}^{\mathrm{P}}}{\mathrm{dt}}\right]$. $\frac{d^{2} \operatorname{In} Y^{P}}{d t^{2}}=$ the change in the rate of change in the perceived

$\beta=$ the adjustment coefficient. $O<\beta \leqslant \infty$. The larger is $\lambda$ the faster is the speed of adjustment.

According to Cagan's procedure, the rate of change in the perceived level of nominal income can be approximated in discrete time by the following:

$$
\begin{aligned}
& \Delta \ln \mathrm{Y}_{\mathrm{H}}^{\mathrm{P}}=\left(1-\mathrm{e}^{-\beta}\right) \underset{\mathrm{i}}{\stackrel{\mathrm{T}}{=} 0} \Delta \ln \mathrm{Y}_{\mathrm{t}-\mathrm{i}} \mathrm{e}^{-\beta \mathrm{I}} . \\
& \left(1-\mathrm{e}^{-\beta}\right) \mathrm{i}_{i=0}^{\frac{T}{2}} \mathrm{e}^{-\beta i}=1 .
\end{aligned}
$$

In the discrete time form of the model, it is asserted that the rate of change in perceived nominal income is that at the begiming of the period. The index (i), therefore, rums from 1 to $T$. Instead of assuming, as Cagan did, various values of $\beta$ and then using their implied values for $\Delta \ln \mathrm{Y}_{t}^{\mathrm{P}}$ directly in the regression equation and selecting the one which has the largest $\overline{\mathrm{R}}^{2}$, the coefficients for each lagged income term were estimated directly. Four lagged changes in nominal income (the lag structure used in this study) implies that $\beta=1.15$, with the 
implied weights $(0.68,0.22,0.07$, and 0.02 ) summing to 0.99. The estinated coefficients for the four lagged income terms, given their standard errors of estimate, are approxi. mately consistent with those implied by these weights.

\section{Tesi for Structural Change}

A test of the hypothesis of a structural change in the coefficients of the model is performed by introducing a zero-one dummy variable into equation (A) of the text. This equation is used rather than Equation B, which incorporates a special assumption regarding the parameters on perceived price and the amount of goods and services that perceived nominal income can purchase. The dummy variable has the value of zero in the $M_{1}$ equation from first quarter 1955 to fourth quarter 1966 and then a value of one to fourth quarter 1973. It has a zero value in the $\mathrm{M}_{2}$ equation from first quarter 1955 to fourth quarter 1961, and then a value of one to fourth quarter 1973.

Two forms of equation (A) are estimated. One is the original specification. The second one has all the original variables, but adds the dummy variable itself (to measure a change in the constant) and the product of the dummy and each of the original variables (to measure a change in the regression coefficients $)^{1}$

If the estimated coefficients for these added variables are not statistically significant from zero, the structural change hypothesis is rejected. An $F$ test is conducted to test the null hypothesis that all the regression coefficients of the added set of variables are equal to zero. If the calculated $F$ value is less than the critical $F$ value, at the five percent level of significance, the null hypothesis is not rejected.

Since the number of lagged $\triangle \mathrm{InQ}$ and $\triangle \mathrm{lnP}$ terms have not been specified at this point, the test for structural change was conducted for lag specifications from one quarter to ten quarters (Table A). For every length of lag, the calculated $F$ value is less than the critical value. As a result, the hypothesis of a structural change in both the $M_{1}$ and $M_{2}$ equations is rejected for each of the lag structures examined.

Toble A

Test For Structural Change Equation (A)

\begin{tabular}{|c|c|c|c|}
\hline \multirow{2}{*}{$\begin{array}{l}\text { Namber } \\
\text { of lags }\end{array}$} & \multicolumn{2}{|c|}{ Colculated } & \multirow{2}{*}{$\begin{array}{l}\text { Crffeal } \\
\text { ( } 05)\end{array}$} \\
\hline & $M_{1}$ & $M_{2}$ & \\
\hline 1 & 164 & 167 & 236 \\
\hline 2 & 1,45 & 103 & 2,17 \\
\hline 3 & 1.58 & 154 & 205 \\
\hline 4 & 105 & 142 & 198 \\
\hline 5 & 89 & $1 / 1$ & 1.93 \\
\hline 6 & 87 & 91 & 100 \\
\hline 7 & 82 & 93 & 1.89 \\
\hline 8 & 75 & 28 & 1.89 \\
\hline 9 & 75 & 121 & $1 \% 1$ \\
\hline 10 & 83 & 112 & 1.91 \\
\hline
\end{tabular}

\section{Determination of Lag Stucture}

A statistical procedure is used to determine the appropriate number of lagged $\Delta \operatorname{lnQ}$ and $\Delta \ln P$ terms in equation (A). Each equation $\left(\mathrm{M}_{1}\right.$ and $\left.\mathrm{M}_{2}\right)$ is estimated eleven times, first with no lags and then increasing the length of lag for $\Delta \ln Q$ and $\Delta \ln P$ by one quarter until ten sets of the two lagged terms are included. The $F$ test is used to test the null hypothesis that the two estimated coefficients for each added lag are zero. If the cal culated $F$ value is greater than the critical value, af the five percent level of significance, the null hypothesis is rejected. Table $B$ shows that the null hypothesis is rejected when lags one and four are added, but not when any of the other lags are added.

\begin{tabular}{|c|c|c|c|}
\hline \multirow{3}{*}{ Edth Added } & \multicolumn{2}{|c|}{ 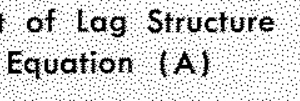 } & \multirow{3}{*}{$\mathrm{Cetso}$} \\
\hline & \multicolumn{2}{|c|}{$\$$ Colculoted $r$} & \\
\hline & $M_{1}$ & $M_{2}$ & \\
\hline 1 & 1880 & 1692 & 400 \\
\hline 2 & 119 & 89 & 400 \\
\hline 3 & 40 & 16 & 400 \\
\hline 4 & 411 & 483 & 400 \\
\hline 5 & 20 & 20 & 400 \\
\hline 6 & 102 & 100 & 400 \\
\hline 7 & 24 & 26 & 4.00 \\
\hline 8 & 124 & 141 & 400 \\
\hline 9 & 39 & 30 & 404 \\
\hline 10 & 230 & 278 & 4.04 \\
\hline \multicolumn{4}{|l|}{ logs } \\
\hline $1-4$ & 6,37 & 609 & 253 \\
\hline 510 & 91 & 100 & 229 \\
\hline
\end{tabular}

The $\vec{F}$ test is next used to test the null hypothesis that as a set all the coefficients for lags one to four are equal to zero. This test, at the five percent level, rejects the null hypothesis (Table B). A similar test is conducted for the coefficients as a set for lags five to ten, when lags one to four are included in the regression. In this second test the null hypothesis cannot be rejected (Table B). On the basis of these results, four lagged $\Delta \ln Q$ and $\Delta \operatorname{lnP}$ terms are considered to be appropriate. Table I in the text presents the estimated coefficients for this specification, equation (A).

\section{Test of Equal Response I}

The hypothesis that the response of desired nominal money balances is the same with regard to both perceived price and the amount of goods and services that nominal income can purchase is tested by imposing a linear constraint on equation (A). An F test is used to test this constraint. If the calculated $F$ value for the constraint is less than the critical value, at the five percent level of significance, the proposition is accepted.

Assuming that the weights in forming $\Delta \mathrm{ln} \mathrm{Q}^{\mathrm{v}}$ and $\Delta \ln P$ are equal for each lag, the equal response hypothesis implies that for each lag the estimated coefficients for $\Delta \ln Q$ and $\Delta \ln P$ are equal. Since by definition 


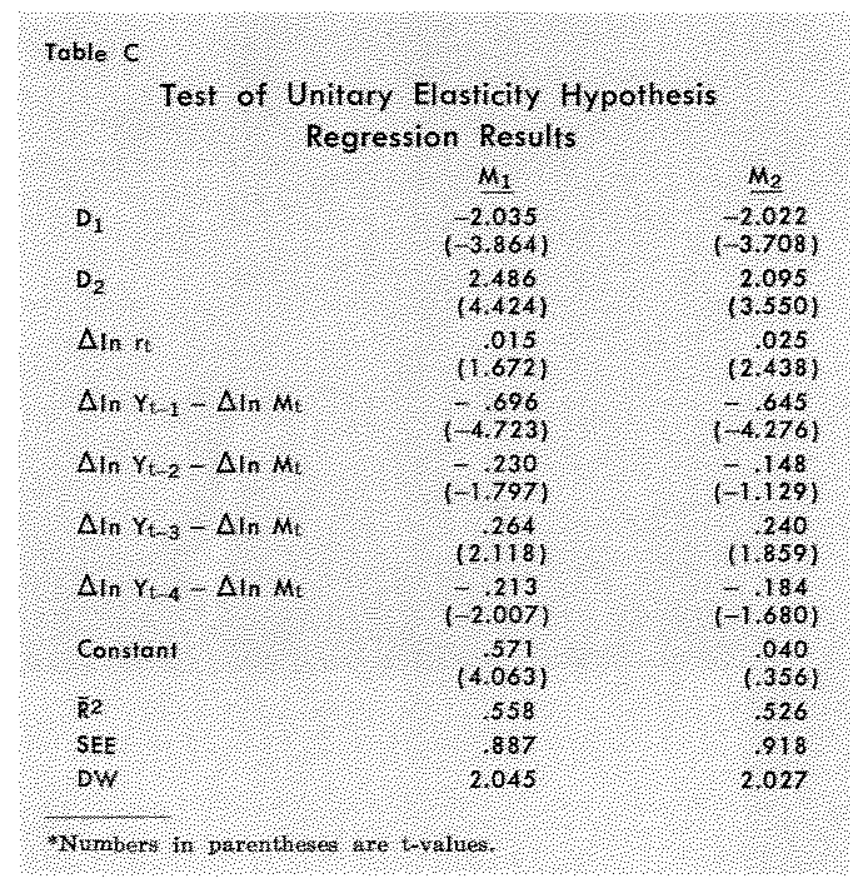

$\Delta \ln Q_{t}+\Delta \ln P_{t}=\Delta \ln Y_{t}$, the coefficients on each set of lagged $\Delta \ln Q$ and $\Delta \ln P$ tems are constrained to be equal by specifying $\Delta \ln Y$ terms (Equation B). Table II of the text presents the estimated coefficients for equation $B$. Regression results for this equation are kested against those for equation (A). The calculated $F$ value are .58 for $M_{1}$ and .64 for $M_{2}$ The critical $F$ value is 2.53 , therefore, the equal response hypothesis is accepted in both cases. These results also lead to the acceptance of the assumptions made regarding the equality of weights in forming $\Delta \ln Q^{p}$ and $\Delta \ln \mathrm{P}^{\mathrm{p}}$,

A frequent hypothesis in monetary economics is that the elasticity of desired money balances with regard to nominal income is unity. Since the weights sum to unity, the hypothesis implies that the coefficient on money in equation (B) is equal to, but opposite in sign, the sum of the coefficients on the lagged $\Delta \ln Y$ terms. This constraint is imposed on equation (B) by dropping the $\Delta \ln M_{t}$ term and subtracting $\Delta \ln M_{t}$ from each of the lagged $\Delta \ln Y$ terms. The regression results are reported in Table $\mathrm{C}$ and are tested against the results for equation (B). The calculated $F$ value for $M_{1}$ is 4.57 and for $M_{2}$ is 7.99. The critical value of $F$ is 4.00 ; therefore, the proposition that the elasticity equals unity is rejected in both cases. The estimated elasticity of desired money balances with regard to perceived nominal income -1.62 for $M_{1}$ and 1.97 for $M_{2}^{2}$, - is derived by dividing the sum of the coefficients on the lagged income terms by the coefficient on money and changing the sign.

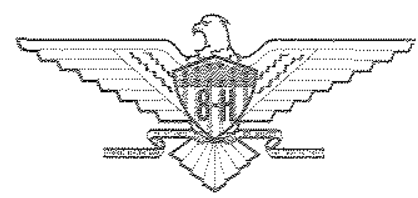

